\title{
Click-Based Libraries of SFTI-1 Peptides: New Methods Using Reversed-Phase Silica
}

Philip A. Cistrone and Philip E. Dawson*

Department of Chemistry, The Scripps Research Institute (TSRI), 10550 N. Torrey Pines Road, La Jolla, California 92037, United States

\section{SUPPORTING INFORMATION}

\section{MATERIALS}

All solvents and chemicals were purchased from commercial sources and used without further purification: DMF (dimethylformamide), $\mathrm{CH}_{3} \mathrm{CN}$ (acetonitrile), $\mathrm{CH}_{2} \mathrm{Cl}_{2}$ (dichloromethane) and $\left(\mathrm{C}_{2} \mathrm{H}_{5}\right)_{2} \mathrm{O}$ (diethyl ether) from Fisher, TFA (trifluoroacetic acid), and DIEA (N,Ndiisopropylethylamine) from Sigma-Aldrich, 4-Methylpiperidine and anisole from Alfa Aesar, bromoacetic acid from Acros Organics, thioacetic acid from Fluka, and HCTU (o-(1benzotriazol-1-yl)-1,1,3,3-tetramethyluronium hexafluorophosphate) from Peptides International. Boc-protected amino acids were purchased from Bachem, and Boc-propargyl glycine (Pra) and Boc- $\beta$-azido alanine (Aza) were purchased from Anaspec. PAM-Leu-Boc resin was purchased from Peptides International. Water was purified using a Millipore Milli-Q water purification system. Peptides were purified by reversed-phase HPLC (RP-HPLC). Analytical RP-HPLC was carried out on an Agilent 1100 Series HPLC on a Phenomenex Jupiter Proteo column (4 $\mu \mathrm{m}, 90$ 
$\AA, 150 \times 4.6 \mathrm{~mm}$ ) at a flow rate of $1 \mathrm{~mL} / \mathrm{min}$. Analytical injections were monitored at $214 \mathrm{~nm}$. Preparative RP-HPLC was performed on a Waters Delta Prep 4000 equipped with a Waters UV detector model 486 and a Phenomenex Jupiter Proteo column $(10 \mu \mathrm{m}, 90 \AA$, $250 \times 21.20 \mathrm{~mm})$ at a flow rate of $15 \mathrm{~mL} / \mathrm{min}$. Preparative injections were monitored at $220 \mathrm{~nm}$.

Peptides were characterized using electrospray ionization MS on a LC/MS API 2000 Plus triple quadrupole mass spectrometer (Sciex). Peptides masses were calculated from the experimental mass to charge $(\mathrm{m} / \mathrm{z})$ ratios from all of the observed protonation states of a peptide by using the onboard analyst software package (Sciex).

\section{PEPTIDE SYNTHESIS}

The P4/P2' SFTI-1 peptide was synthesized by first functionalizing PAM-Leu-Boc resin with a standard thioester linker (mercaptoacetic acid) for Native Chemical Ligation (NCL) following synthesis and cleavage from resin. The peptide was chain assembled from the P4 Pra residue in the N-terminal direction to the P3 Cys residue, affording the cyclic peptide upon NCL. All amino acid couplings were carried out with the equivalent ratio of [5]:[5]:[7.5] of [amino acid]:[0.4 M HCTU in DMF]:[DIEA] for 20 minutes following standard SPPS protocol with Nterminal Boc-protection. Pra and Aza residues were coupled using the equivalent ratio of [2]:[2]:[3.2] of these components for 40 minutes, and followed by a qualitative ninhydrin test to ensure complete coupling. Following standard cleavage from resin by anhydrous HF, NCL was carried out by standard protocol: $6 \mathrm{M}$ guanidine hydrochloride and $200 \mathrm{mM}$ sodium phosphate buffer, $\mathrm{pH} 8.1$, with $0.1 \%$ thiophenol, at $1 \mathrm{mg} / \mathrm{mL}$ concentration for 4 hours. Following purification, the peptide was oxidized (100 $\mathrm{mM} \mathrm{NH}_{4} \mathrm{HCO}_{3}, \mathrm{pH} 8.1,0.1 \mathrm{mg} / \mathrm{mL}$ concentration) to form the final disulfide bridged bicyclic product. 


\section{CuAAC REACTION \#1}

Free particulate reversed-phase C18 silica (Phenomenex) was swelled overnight in 1:1 $\mathrm{H}_{2} \mathrm{O}$ :EtOH. Approximately $150 \mu \mathrm{L}$ of swelled silica was added to a PCR tube and centrifuged to a bed volume of $40 \mu \mathrm{L}$, following the removal of the swelling supernatant.

The azide- and alkyne-containing peptide ( $0.2 \mathrm{mg}, 2.5 \mathrm{mM}$ final concentration) was dissolved in $37 \mu \mathrm{L}$ of $\mathrm{H}_{2} \mathrm{O}$ and $11 \mu \mathrm{L}$ of EtOH in the PCR tube containing the silica. The azide small molecule (20 eq.) was added to the peptide solution and vortexed until dissolved. Separately, 2.7 $\mu \mathrm{L}$ of $50 \mathrm{mM}$ THPTA ligand (Tris(2-hydroxypropyltriazoylmethyl)amine) in water (1 eq. to peptide) and $1.4 \mu \mathrm{L}$ of $20 \mathrm{mM} \mathrm{CuSO}$ (from $\mathrm{CuSO}_{4} \cdot 5 \mathrm{H}_{2} \mathrm{O}$ ) in water ( 0.2 eq. to peptide) were combined. This mixture was then added to the PCR tube, followed by $3.4 \mu \mathrm{L}$ of $0.1 \mathrm{M}$ sodium ascorbate in water ( 2.5 eq. to peptide) to initiate the reaction. The vial was placed on a rotator/shaker on low setting.

To monitor the reaction, $10 \mu \mathrm{L}$ of the reaction mixture was combined with $190 \mu \mathrm{L}$ of HPLC Buffer A $\left(100 \% \mathrm{H}_{2} \mathrm{O}\right.$ with $0.05 \%$ TFA) and injected on analytical RP-HPLC (0\% B to 60\% B in 30 minutes gradient, Phenomenex Jupiter Proteo $4 \mu 90 \AA ̊$ column, 150 x 4.6 mm). Depending on the azide or alkyne being conjugated to the peptide and on the peptide itself, the reaction will take between 4 hours and 24 hours to finish ( $>95 \%$ product by analytical RP-HPLC, confirmed by ESI-MS).

After reaction completion, the silica was rinsed 3 times with $100 \mu \mathrm{L}$ of $20 \%$ Buffer B (90\%:10\% ACN: $\mathrm{H}_{2} \mathrm{O}$ with $0.05 \%$ TFA) in Buffer A. This procedure removes all excess reactants while leaving the peptide product immobilized on the support.

\section{CuAAC REACTION \#2}


The following click reaction was set up nearly identically to the first, with the exception of 10 eq. of small molecule to peptide instead of 20 eq. The small molecule alkyne was dissolved in $37 \mu \mathrm{L}$ of $\mathrm{H}_{2} \mathrm{O}$ and $11 \mu \mathrm{L}$ of EtOH in the PCR tube containing the silica. Separately, $2.7 \mu \mathrm{L}$ of 50 mM THPTA ligand (Tris(2-hydroxypropyltriazoylmethyl)amine) in water (1 eq. to peptide) and $1.4 \mu \mathrm{L}$ of $20 \mathrm{mM} \mathrm{CuSO}_{4}$ (from $\mathrm{CuSO}_{4} \cdot 5 \mathrm{H}_{2} \mathrm{O}$ ) in water ( 0.2 eq. to peptide) were combined. This mixture was then added to the PCR tube, followed by $3.4 \mu \mathrm{L}$ of $0.1 \mathrm{M}$ sodium ascorbate in water (2.5 eq. to peptide) to initiate the reaction. The vial was placed on a rotator/shaker on low setting.

After 4 hours, the reaction progression was monitored in the same manner as the first using analytical RP-HPLC, and the identity of the final product peptide was confirmed by ESI-MS. 

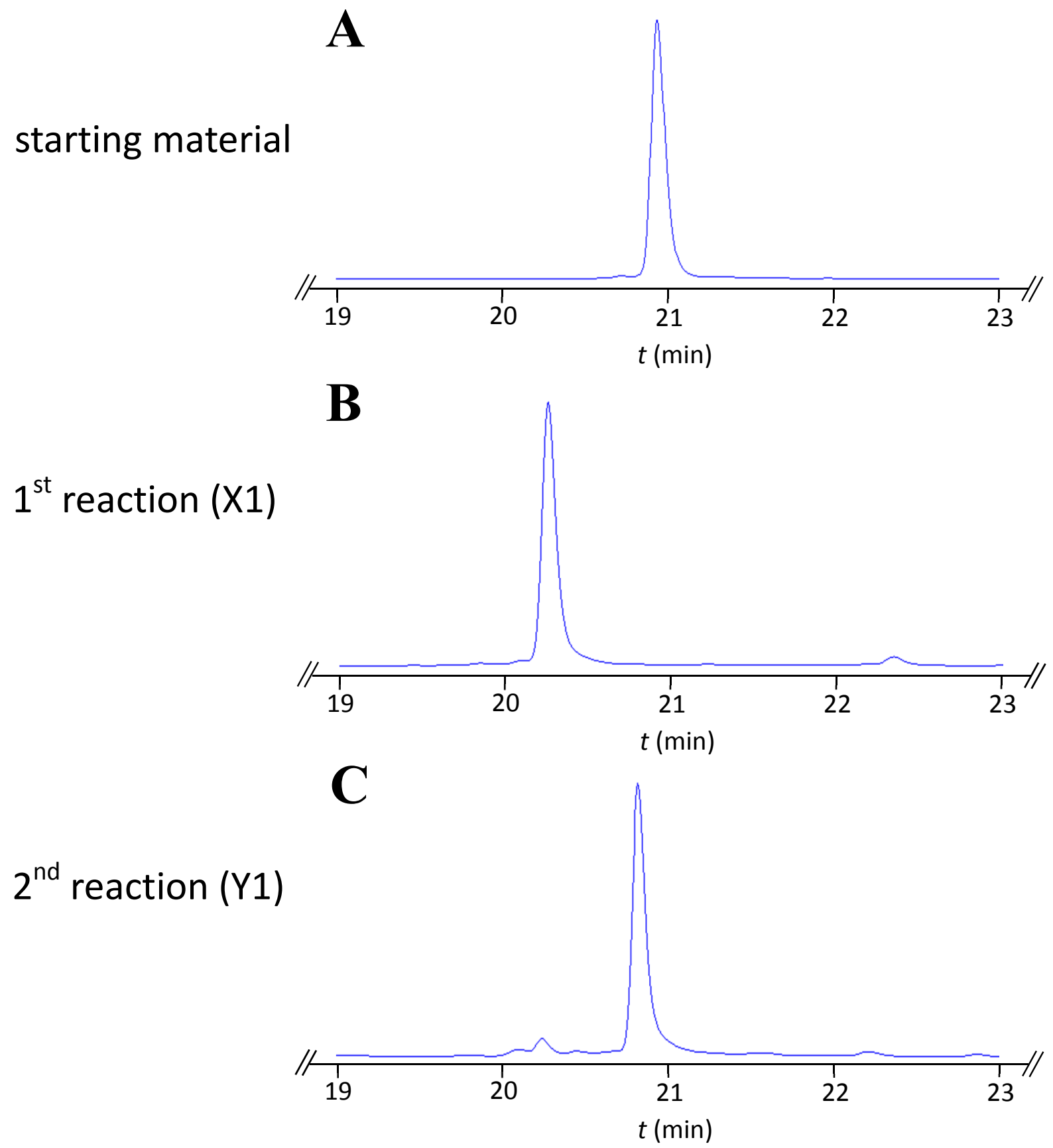

Figure S1: Representative RP-HPLC traces monitored at $214 \mathrm{~nm}$ from reaction X1Y1. The time window of 19 min - 23 min is shown from a 40 min run of gradient $0 \%$ Buffer B to $60 \%$ Buffer B. Trace A is the starting material P4/P2' SFTI-1 peptide $(20.9 \mathrm{~min})$. Trace $\mathrm{B}$ is the $1^{\text {st }}$ reaction ( $100 \%$ conversion by peak area, $20.3 \mathrm{~min}$ ). Trace $\mathrm{C}$ is the $2^{\text {nd }}$ reaction $(95 \%$ conversion by peak area, $20.9 \mathrm{~min})$. 

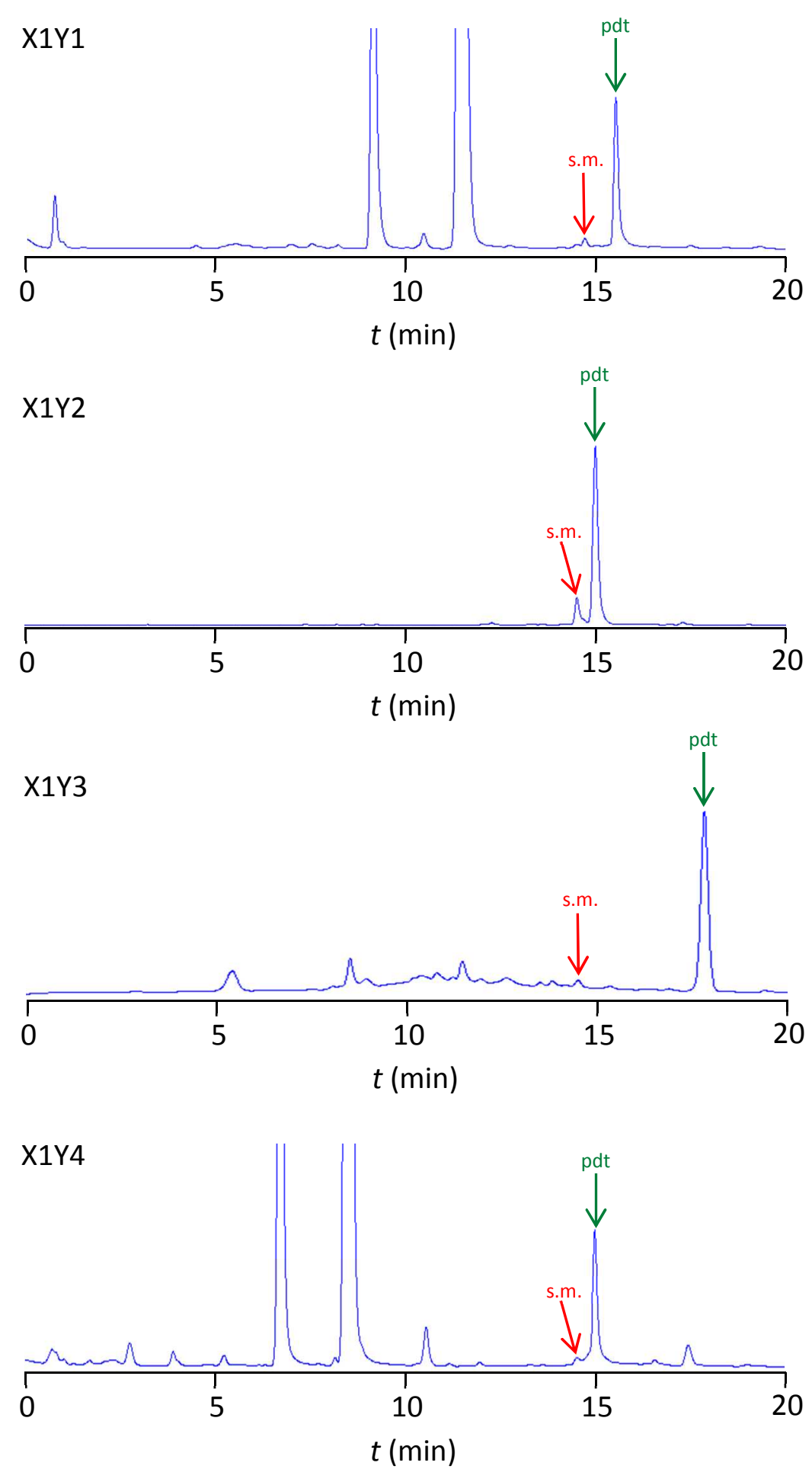

Figure S2a: Reaction RP-HPLC traces monitored at $214 \mathrm{~nm}$ for reactions X1Y1 through X1Y4. Starting material "s.m." is the peptide after the click reaction to X1. Product "pdt" is the doublyclicked final peptide. After injection, the column was run at $20 \%$ Buffer B for 20 minutes as a wash step, and followed by a $20 \%$ Buffer B to $60 \%$ Buffer B gradient over 20 min (gradient trace shown above). Some reactants washed away more than others in the allotted time, but the peptides remained at a constant elution point due to their multivalent binding characteristics. 

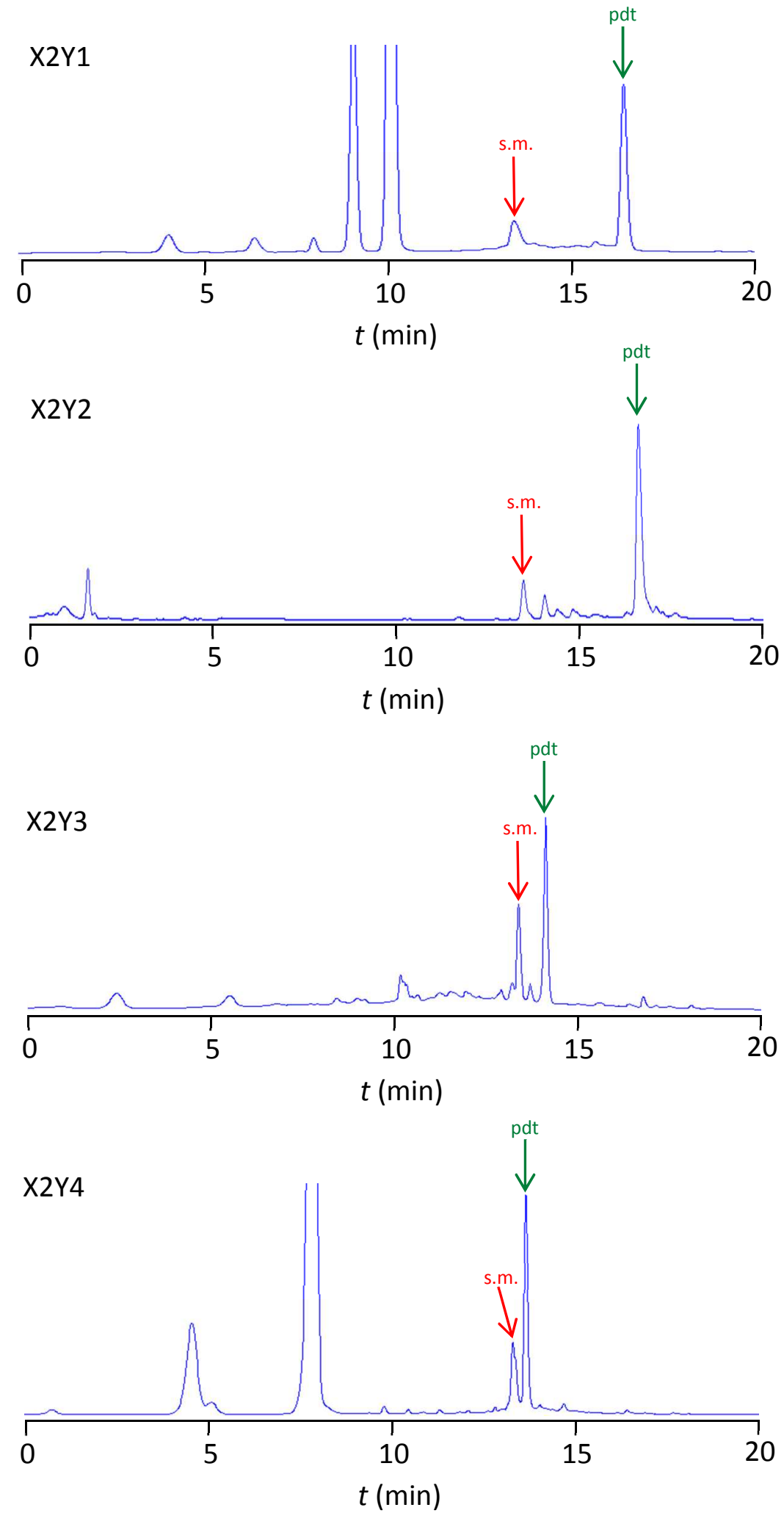

Figure S2b: Reaction RP-HPLC traces monitored at $214 \mathrm{~nm}$ for reactions X2Y1 through X2Y4. Starting material "s.m." is the peptide after the click reaction to X1. Product "pdt" is the doublyclicked final peptide. After injection, the column was run at $20 \%$ Buffer B for 20 minutes as a wash step, and followed by a $20 \%$ Buffer B to $60 \%$ Buffer B gradient over 20 min (gradient trace shown above). Some reactants washed away more than others in the allotted time, but the peptides remained at a constant elution point due to their multivalent binding characteristics. 

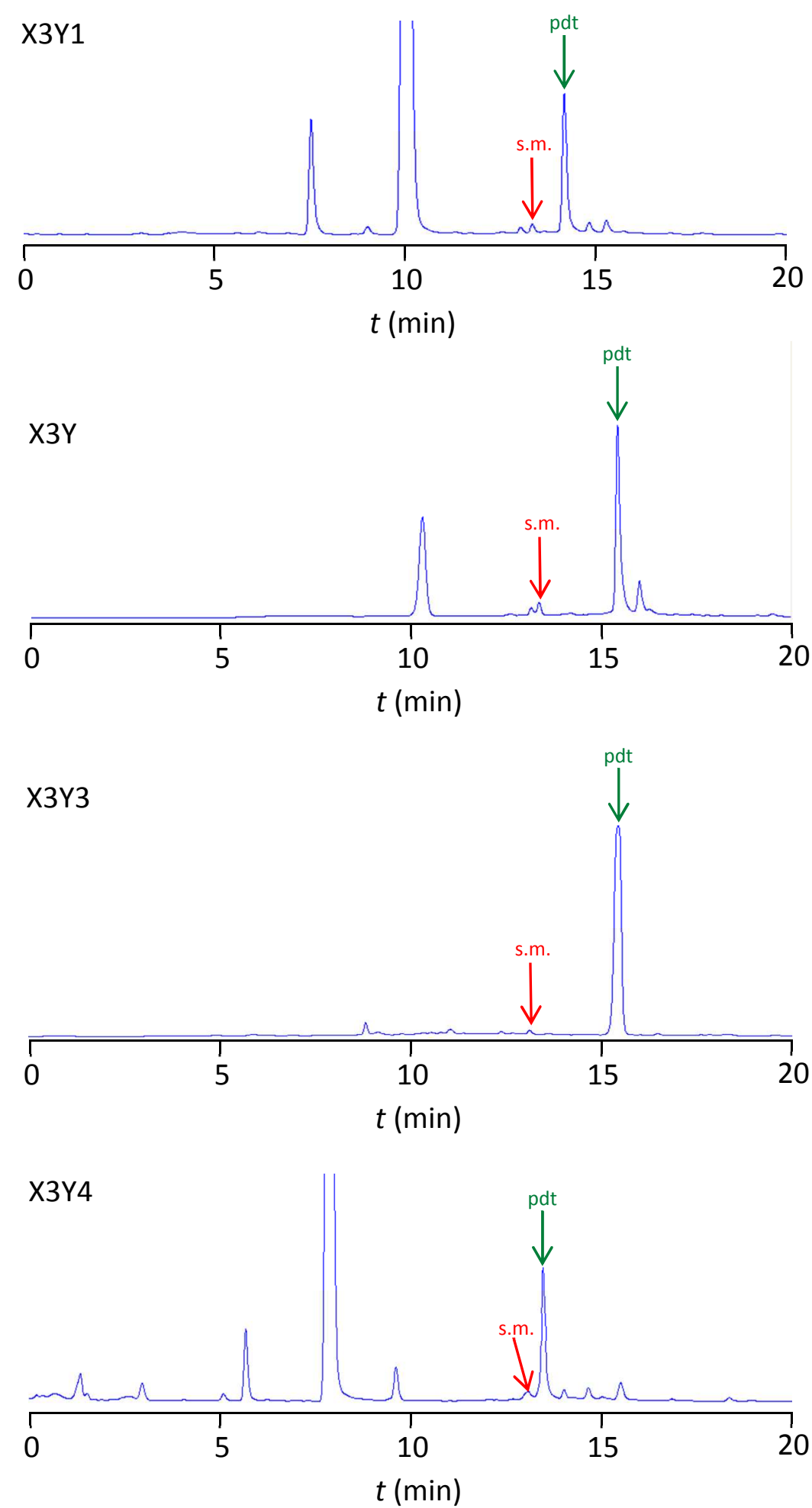

Figure S2c: Reaction RP-HPLC traces monitored at $214 \mathrm{~nm}$ for reactions X3Y1 through X3Y4. Starting material "s.m." is the peptide after the click reaction to X1. Product "pdt" is the doublyclicked final peptide. After injection, the column was run at $20 \%$ Buffer B for 20 minutes as a wash step, and followed by a $20 \%$ Buffer B to $60 \%$ Buffer B gradient over 20 min (gradient trace shown above). Some reactants washed away more than others in the allotted time, but the peptides remained at a constant elution point due to their multivalent binding characteristics. 

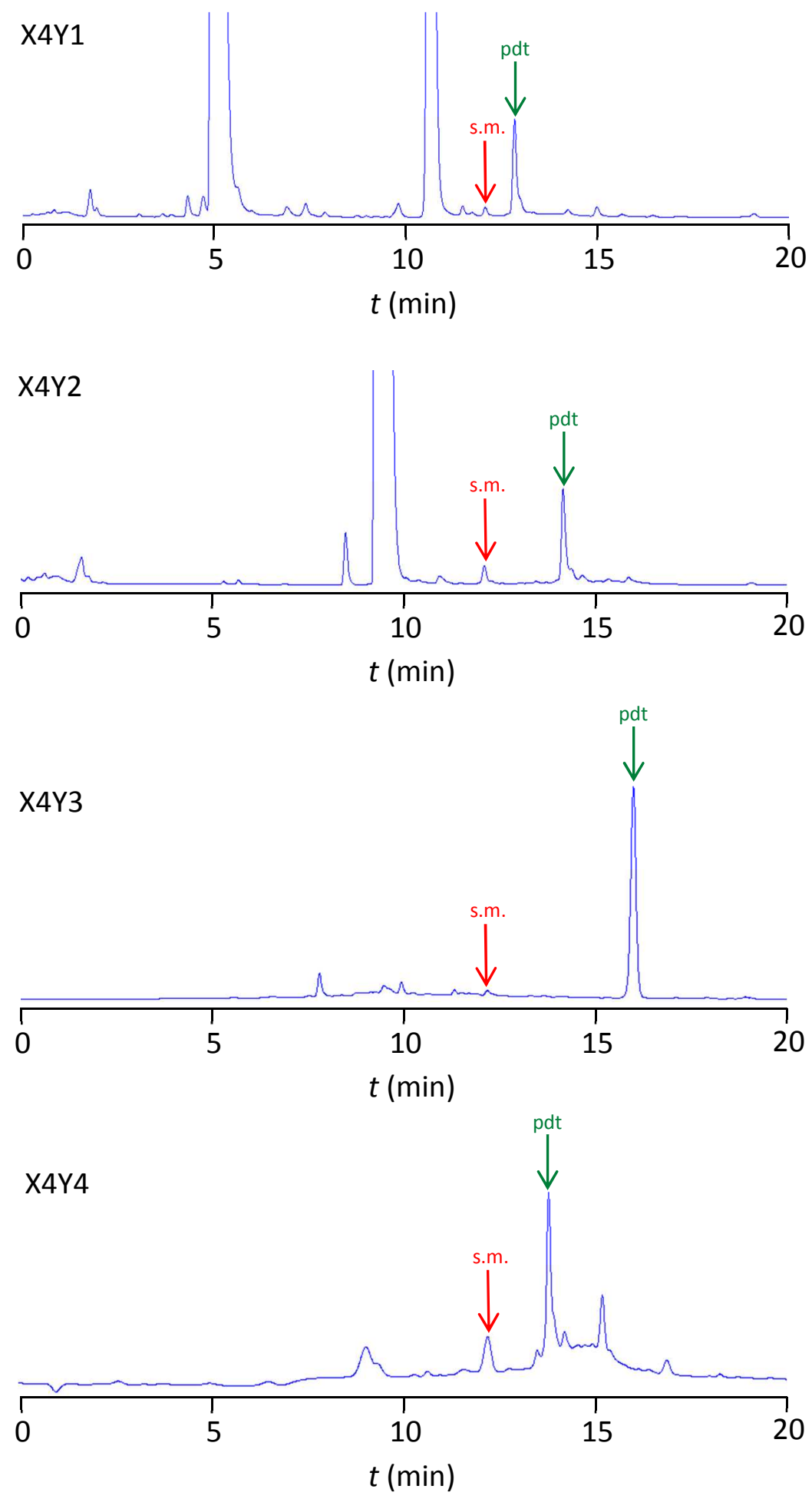

Figure S2d: Reaction RP-HPLC traces monitored at $214 \mathrm{~nm}$ for reactions X4Y1 through X4Y4. Starting material "s.m." is the peptide after the click reaction to X1. Product "pdt" is the doublyclicked final peptide. After injection, the column was run at $20 \%$ Buffer B for 20 minutes as a wash step, and followed by a $20 \%$ Buffer B to $60 \%$ Buffer B gradient over 20 min (gradient trace shown above). Some reactants washed away more than others in the allotted time, but the peptides remained at a constant elution point due to their multivalent binding characteristics. 